\title{
Cytomegalovirus Mononucleosis in Chinese Infants
}

\author{
W. Y. LUI and W. K. CHANG \\ From the Department of Paediatrics, University of Hong Kong, and the Virus Unit, Medical and Health Department, \\ Hong Kong
}

\begin{abstract}
Lui, W. Y., and Chang, W. K. (1972). Archives of Disease in Childhood, 47, 643. Cytomegalovirus mononucleosis in Chinese infants. Two Chinese infants had cytomegalovirus inclusion disease presenting as persistent pneumonia and thrombocytopenic purpura, respectively. Both had lymphadenopathy, hepatosplenomegaly, pneumonia, and more than $14 \%$ atypical lymphocytes in the peripheral blood at some stage of the disease. The Paul-Bunnell reactions were serially negative. A clinical picture simulating infectious mononucleosis, including the presence of a high percentage of atypical lymphocytes in the peripheral blood, but serially negative Paul-Bunnell reactions, may be one of the many manifestations of cytomegalovirus inclusion disease in infancy and childhood.
\end{abstract}

Cytomegalovirus mononucleosis in adults has been described by Klemola and Kääriäinen (1965), Toghill et al. (1967), Kääriäinen, Klemola, and Paloheimo (1966a), and Stern (1968). The literature on such a presentation in infants and children is, however, scanty. This report presents two Chinese infants with cytomegalovirus inclusion disease and an infectious mononucleosis-like peripheral blood picture. Cytomegalovirus was isolated in both cases. One had a rising complement-fixing antibody titre against the virus. One died, and necropsy examination confirmed the diagnosis.

\section{Case Reports}

Case 1. A 7 $\frac{1}{2}$-month-old girl had had a continuous fever of $38-40^{\circ} \mathrm{C}$, and respiratory distress since 6 months of age, and failed to respond to various antibiotics and antituberculous drugs. She was a term baby, birthweight $3150 \mathrm{~g}$, head circumference $31 \mathrm{~cm}$, and body length $50 \mathrm{~cm}$. Her mother had been treated for 'monilial vaginitis' at 36 weeks pregnancy. The baby's condition at birth was good, but it had transient mild jaundice of unknown cause from the fourth to the sixth day. She had head control at 5 months and was unable to sit unaided at $7 \frac{1}{2}$ months.

On admission her weight was between the 10th and 25th centile of normal Chinese girls of her age, her height was on the 90th centile, and head circumference 25th centile. She had a maculopapular rash over her trunk and extremities, and palpable lymph nodes in her neck, axillae, and groins. Her rectal temperature was $40^{\circ} \mathrm{C}$, respiratory rate $65 / \mathrm{min}$ regular. She was cyanotic,

Received 14 December 1971. with generalized intercostal insucking, signs of collapse of the right lung, and diffuse crepitations on the left side. Her pharynx and oral mucosa were congested. The liver was $6 \frac{1}{2} \mathrm{~cm}$ below the right costal margin at the midclavicular line, and the spleen $4 \mathrm{~cm}$. $\mathrm{Hb}$ was 11.5 $\mathrm{g} / 100 \mathrm{ml}$, PCV $38 \%$, WBC $12,800 / \mathrm{mm}^{3}$, with $41 \%$ polymorphs, $44 \%$ lymphocytes, and $15 \%$ atypical lymphocytes, platelets $197,500 / \mathrm{mm}^{3}$, reticulocyte count $0.1 \%, \mathrm{ESR} 30 \mathrm{~mm} / 1$ st hour (Westergren), blood $p \mathrm{H}$ $7 \cdot 48, \mathrm{PCO}_{2} 40.5 \mathrm{~mm}$, standard bicarbonate $29 \mathrm{mEq} / 1$. On bronchoscopy, no foreign body was found but the right bronchus was filled with thick whitish secretions. Bronchial toileting was done. Her tuberculin tests were repeatedly negative. Routine examination of urine, stool, CSF; cultures of blood, urine, throat, nasal and bronchial secretions; cultures of gastric lavages for acid-fast bacilli; blood for mono test; Paul-Bunnell tests; and Widal tests were all negative. Cytomegalovirus was isolated from her urine. Her serum complementfixing antibody titre against this virus was $1: 40$. Other viruses and organisms were not isolated from throat, nasal swabs, and stools. Cultures for viruses done on the mother were all negative. The mother's serum antibody titre against cytomegalovirus could not be tested due to persistent anticomplementary activity of the serum.

The baby died a few days after admission. Necropsy examination revealed necrotizing inflammation of the whole respiratory tract. The trachea, bronchi, and bronchioles were filled with cellular debris and necrotic material. Alveolar walls were thickened and alveolar spaces filled with mononuclears, desquamated epithelium, and large cells containing intranuclear and cytoplasmic inclusions typical of cytomegalovirus inclusion disease (Fig. 1). Scattered areas of small haemorrhages were seen in both lungs. Inclusions were also seen in renal tubules but not in other organs. The liver showed 


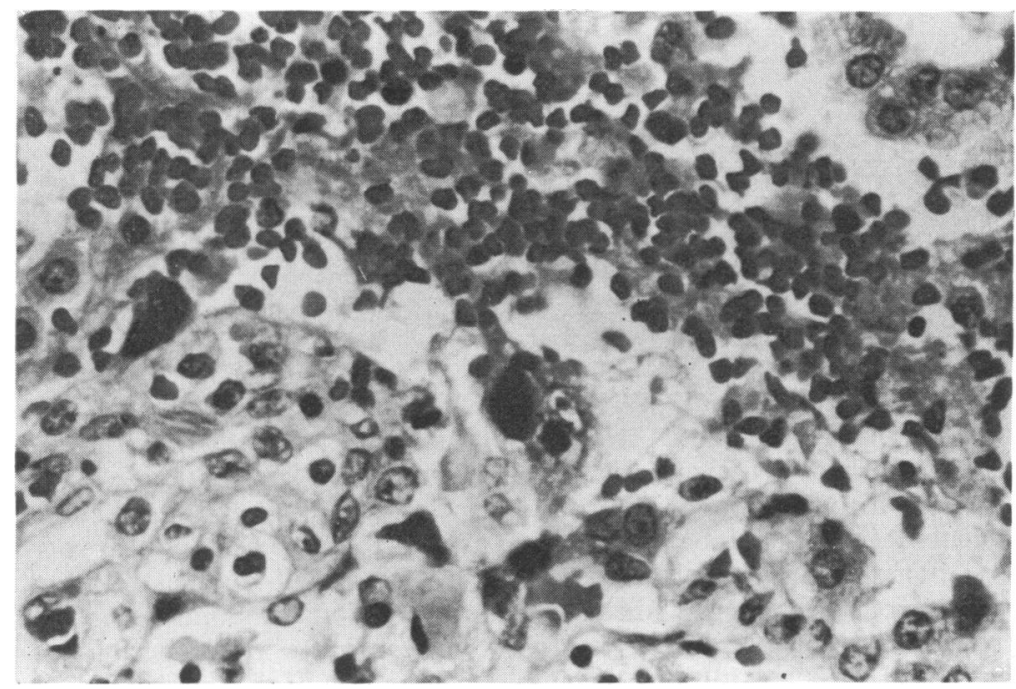

FIG. 1.-Lung of Case 1 showing inclusion-bearing alveolar living cells. $(\times 480$.

moderate fatty degeneration. There was no evidence of tuberculosis or fungal infections.

Case 2. A 4-month-old girl was admitted with a two-week history of generalized petechiae. She was delivered at 36 weeks' gestation by vacuum extraction for maternal contracted pelvis. Her Apgar score at birth was 10, weight $2710 \mathrm{~g}$, head circumference $28 \mathrm{~cm}$, and body length $48 \mathrm{~cm}$. At the 6th day she was jaundiced, and her serum total bilirubin at day 7 was $20 \cdot 2 \mathrm{mg} / 100 \mathrm{ml}$, falling to $18 \mathrm{mg} / 100 \mathrm{ml}$ after 6 hours, and $15 \cdot 1 \mathrm{mg} / 100 \mathrm{ml}$ next day. No exchange transfusion was done. She was discharged at day 10 with a total serum bilirubin of $8.5 \mathrm{mg} / 100 \mathrm{ml}$. No obvious cause for her jaundice was found. The mother had been treated for monilial vaginitis at 33 weeks' pregnancy. The baby had head control at $2 \frac{1}{2}$ months.

On admission, her body weight was between the 3rd and 10 th centile, height 50 th centile, and head circumference 10th centile. She had petechiae over her face, trunk, and extremities, and enlarged lymph nodes in her neck and groins. The liver was $3 \mathrm{~cm}$ below the right costal margin at the midclavicular line and firm. The spleen was not palpable. She had no fever. Her chest was clear on auscultation but showed radiological signs of pneumonitis in the left middle and right lower zones, which persisted for 6 weeks. Hb was 12 g/100 ml, PCV $26 \cdot 6 \%$, WBC $13,500 / \mathrm{mm}^{3}, 32 \%$ polymorphs, $62 \%$ lymphocytes, $2 \%$ eosinophils, and $4 \%$ monocytes, platelet $1800 / \mathrm{mm}^{3}$, reticulocyte count $0.1 \%$, and atypical lymphocytes were not found. Her bleeding time was 18 minutes, clotting time 3 minutes, clot retraction poor, PTT 46 sec (control 42 sec). Prothrombin time $12 \mathrm{sec}$ (control 11), and Coombs test negative. Marrow biopsy showed normal erythropoiesis, increased lymphocytes, increased number of immature megakaryocytes, and no malignant cells.
Serum bilirubin was $1.8 \mathrm{mg} / 100 \mathrm{ml}$ with direct reacting $1.7 \mathrm{mg} / 100 \mathrm{ml}$, SGOT $61 \mathrm{RF}$ units/ml, SGPT 30 $\mathrm{RF}$ units/ml, alkaline phosphatase $37 \mathrm{KA}$ units $\%$, serum creatinine $0.3 \mathrm{mg} / 100 \mathrm{ml}$.

Five days after admission her temperature rose to $37 \cdot 8^{\circ} \mathrm{C}$. The spleen became palpable $3 \mathrm{~cm}$ below her left costal margin. Petechiae persisted in repeated crops. Her $\mathrm{Hb}$ was $10.5 \mathrm{~g} / 100 \mathrm{ml}$, WBC $11,500 /$ $\mathrm{mm}^{3} ; 29 \%$ polymorphs, $50 \%$ lymphocytes, $1 \%$ eosinophils, and $20 \%$ atypical lymphocytes (Fig. 2) were present. The reticulocyte count was $2 \%$ and platelet $2000 / \mathrm{mm}^{3}$. Paul-Bunnell and mono-tests were serially negative. There was no bile or excessive urobilinogen in the urine. Glucose-6-phosphate-dehydrogenase was not deficient. Warm and cold agglutinins, LE cells, and common virus studies were all negative.

After the first 10 days of hospitalization, the platelet count rose spontaneously to between 18,000 and 35,000 / $\mathrm{mm}^{3}$ for the following two weeks, but new crops of petechiae and purpura appeared repeatedly. Atypical lymphocytes persisted in peripheral blood in excess of $15 \%$ for two weeks and gradually decreased thereafter. Liver and spleen were still $3 \mathrm{~cm}$ below costal margins and firm. Liver function tests done 18 days after admission showed serum bilirubin $1.1 \mathrm{mg} / 100 \mathrm{ml}$, with $0.9 \mathrm{mg} / 100 \mathrm{ml}$ direct-reacting, SGOT $176 \mathrm{RF}$ units/ml, SGPT $188 \mathrm{RF}$ units/ml, alkaline phosphatase $20.4 \mathrm{KA}$ units \%. Due to the persistent bleeding tendency 5 weeks after the onset, she was then given prednisone $2 \cdot 2 \mathrm{mg} / \mathrm{kg}$ weight per day. Two weeks later, platelet count rose from 55,000 to $85,000 / \mathrm{mm}^{3}$, and atypical lymphocytes fell to $7 \%$. No more fresh crops of petechiae appeared. One month after starting prednisone platelet count was 175,000 to $240,000 / \mathrm{mm}^{3}$, monocytes $4 \%$, and $\mathrm{Hb} 13.2 \mathrm{~g} / 100 \mathrm{ml}$.

Cultures for cytomegalovirus done on admission were known to be positive from her saliva and urine. 


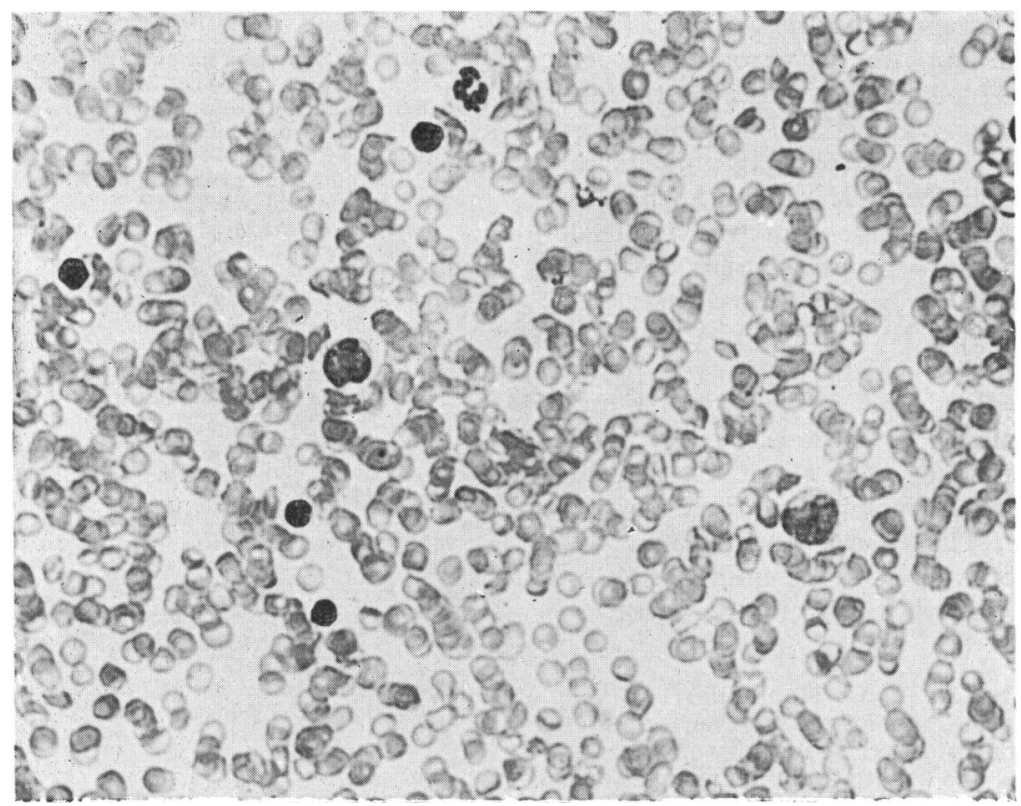

Fig. 2.-Peripheral blood of Case 2 showing mononucleosis. ( $\times$ 540.)

Continuous positive cultures persisted for two months. Complement-fixing antibody titre against $\mathrm{CMV}$ was $1: 40$ on admission, $1: 3207$ weeks later, and persisted at $1: 320$ when tested 3 and 5 months after the onset of petechiae. At $8 \frac{1}{2}$ months, her serum IgG was 1500 $\mathrm{mg} / 100 \mathrm{ml}$, IgA $25 \mathrm{mg} / 100 \mathrm{ml}$, and IgM $88 \mathrm{mg} / 100 \mathrm{ml}$. The baby was discharged 2 months after admission and prednisone was tapered off and stopped 6 weeks after starting it. Platelet counts were normal and she had no more petechiae. $2 \frac{1}{2}$ months after discharge, she was completely normal. The liver was just palpable, spleen not palpable. Her serum bilirubin was normal, SGPT $24 \mathrm{RF}$ units/ml, SGOT $52 \mathrm{RF}$ units/ml. Virus cultures done on the mother were repeatedly negative and her complement-fixing antibody titre against CMV was $1: 40$ on the baby's admission and $4 \frac{1}{2}$ months later.

\section{Discussion}

Cytomegalovirus mononucleosis in adults occurs in previously healthy persons (Klemola et al., 1969), after blood transfusions (Kääriäinen et al., 1966b), and in patients with immunodeficiency states. Clinical manifestations include fever, myalgia, headache, rash, pneumonia, carditis, polyneuritis, and cholestatic hepatitis. Pharyngitis, lymphadenopathy, and hepatomegaly may or may not be present. The blood picture resembles that of infectious mononucleosis with atypical lymphocytes of various types. The Paul-Bunnell test is negative. Stern (1968) investigated 11 children aged 5 to 15 years with Paul-Bunnell negative glandular fever. Cyto- megalovirus was isolated from only one 6-year-old boy. Klemola described a girl of 1 year 10 months with arthritis, pneumonia, mononucleosis in peripheral blood, and raised titre of complementfixing antibodies to cytomegalovirus, but no such virus was isolated. Zuelzer et al. (1970) noted autoimmune haemolytic anaemia, neutropenia, and thrombocytopenia associated with cytomegalovirus infections but made no remarks on 'mononucleosis'.

Atypical mononuclear leucocytosis in peripheral blood is probably a nonspecific response of lymphocytes to various stimuli especially virus infections (Vaughn and Greenberg, 1962). A peripheral blood count of atypical lymphocytes in excess of $10 \%$ has not so far been found to be associated with other virus infections in Hong Kong Chinese children. Neither have the authors seen a Chinese child with heterophil-positive infectious mononucleosis even on serial testing for the heterophil reaction. In both patients presented there were pneumonia, lymphadenopathy, hepatosplenomegaly, and mononucleosis in peripheral blood. The first baby presented predominantly as persistent pneumonia simulating closely tuberculosis which is still not uncommon in Hong Kong. The maculopapular rash could easily have been attributed to drugs. However, tuberculin tests were repeatedly negative, and though monocytic reaction could occur in tuberculosis, atypical lymphocytes in excess of $10 \%$ in peripheral blood have not been our 
experience in Chinese children. The second patient presented initially as thrombocytopenic purpura. Fever, splenomegaly, and mononucleosis appeared only later. Hepatitic and pulmonary involvement were detected only by biochemical and radiological examinations. In both, the PaulBunnell tests were serially negative. Cytomegalovirus was isolated from the urines of both babies, and also from the saliva of the second case. The complement-fixing antibody titre against $\mathrm{CMV}$ rose from $1: 40$ to $1: 320$ in the second patient. Necropsy in the first case showed typical intranuclear and cytoplasmic inclusions. It is interesting to note that in both cases there was a history of maternal 'monilial vaginitis' during the pregnancy. However, CMV was not isolated from either mother on repeated examinations, and monilia was not isolated from either patient.

We are grateful to Drs. C. C. Shih and W. C. Chan of the Department of Pathology, University of Hong Kong, for their comments on the pathology and preparation of photographs, and also to the Director of Medical and Health Services, Hong Kong, for his permission to publish this paper.
REFERENCES

Kääriäinen, L., Klemola, E., and Paloheimo, J. (1966a). Rise of cytomegalovirus antibodies in an infectious-mononucleosis-like syndrome after transfusion. British Medical fournal, 1, 1270.

Kääriăinen, L., Paloheimo, J., Klemola, E., Mäkelä, T, and Koivuniemi, A. (1966b). Cytomegalovirus-mononucleosis: isolation of the virus and demonstration of subclinical infections after fresh blood transfusion in connection with open-heart surgery. Annales Medicinae Experimentalis et Biologiae Fenniae, 44, 297.

Klemola, E., von Essen, R., Wager, O., Haltia, K., Koivuniemi, A., and Salmi, I. (1969). Cytomegalovirus mononucleosis in previously healthy individuals. Annals of Internal Medicine, 71, 11.

Klemola, E., and Kääriäinen, L. (1965). Cytomegalovirus as a possible cause of a disease resembling infectious mononucleosis. British Medical fournal, 2, 1099.

Stern, H. (1968). Isolation of cytomegalovirus and clinical manifestations of infection at different ages. British Medical Journal, 1, 665.

Toghill, P. J., Bailey, M. E., Williams, R., Zeegen, R., and Bown, R. (1967). Cytomegalovirus hepatitis in the adult. Lancet, 1, 1351.

Vaughn, J, and Greenberg, S. D. (1962). The significance of atypical mononuclear leukocytes. fournal of Pediatrics, 60, 177.

Zuelzer, W. W., Mastrangelo, R., Stulberg, C. S., Poulik, M. D., Page, R. H., and Thompson, R. I. (1970). Autoimmune hemolytic anemia: natural history and viral-immunologic interactions in childhood. American fournal of Medicine, 49, 80.

Correspondence to Dr. W. Y. Lui, Department of Paediatrics, Queen Mary Hospital, Hong Kong. 